Ana Cristina Neves Figueiredo'

Paula Elisa Folgado da Siva Ambrósio Reme o Duarte ${ }^{2}$ Tereza Paula Monteiro Gomes²

Jorge Manuel Paiva Borrego²

Carlos Alfredo Caseiro Marques ${ }^{3}$

Artigo Original

Keywords

Bartholin's gland/therapy Cysts/therapy

Laser therapy

Lasers, gas/therapeutic use Ambulatory surgical procedures

Palavras-chave

Glândula de Bartholin/terapia Cistos/terapia Terapia a laser

Laser de gás/uso terapêutico Procedimentos cirúrgicos ambulatórios

\title{
Bartholin's gland cysts: management with carbon-dioxide laser vaporization
}

\author{
Cistos da glândula de Bartholin: tratamento com vaporização \\ laser com $\mathrm{CO}_{2}$
}

Abstract

PURPOSE: To evaluate the effectiveness, recurrence rate, and complications of carbon-dioxide laser vaporization in the treatment of Bartholin's gland cysts. METHODS: A retrospective study including 127 patients with symptomatic Bartholin' gland cysts submitted to carbon-dioxide laser vaporization at our institution from January 2005 to June 2011. Patients with Bartholin's gland abscesses and those suspected of having neoplasia were excluded. All procedures were performed in an outpatient setting under local anaesthesia. Clinical records were reviewed for demographic characteristics, anatomic parameters, intraoperative and postoperative complications, and follow-up data. Data were stored and analyzed in Microsoft Excel ${ }^{\circledR} 2007$ software. A descriptive statistical analysis was performed, and its results were expressed as frequency (percentage) or mean \pm standard deviation. Complication, recurrence, and cure rates were calculated. RESULTS: The mean age of the patients was 37.3 \pm 9.5 years-old (range from 18 to 61 years-old). Seventy percent $(n=85)$ of them were multiparous. The most common symptom was pain and $47.2 \%(n=60)$ of patients had a history of previous medical and/or surgical treatment for Bartholin's gland abscesses. Mean cyst size was $2.7 \pm 0.9 \mathrm{~cm}$. There were three $(2.4 \%)$ cases of minor intraoperative bleeding. Overall, there were $17(13.4 \%)$ recurrences within a mean of 14.6 months (range from 1 to 56 months): ten Bartholin's gland abscesses and seven recurrent cysts requiring reintervention. The cure rate after single laser treatment was $86.6 \%$. Among the five patients with recurrent disease that had a second laser procedure, the cure rate was 100\%. CONCLUSIONS: At this institution, carbon-dioxide laser vaporization seems to be a safe and effective procedure for the treatment of Bartholin's gland cysts.

\section{Resumo}

OBJETIVO: Avaliar a eficácia, a taxa de recorrência e as complicações da vaporização laser com $\mathrm{CO}_{2}$ no tratamento dos cistos da glândula de Bartholin. MÉTODOS: Estudo retrospectivo com 127 pacientes que apresentavam cistos sintomáticos da glândula de Bartholin submetidas à vaporização laser $\mathrm{CO}_{2}$ na nossa instituição de janeiro de 2005 a junho de 2011 . Foram excluídas todas as pacientes com abcessos da glândula de Bartholin ou com suspeita de câncer. Todos os procedimentos foram realizados em regime ambulatorial, sob anestesia local. A coleta dos dados foi feita com base na consulta do processo clínico, tendo-se procedido à análise das características demográficas, dos parâmetros anatômicos, das complicações intra e pós-operatórias e dos dados de acompanhamento. Os dados foram armazenados e analisados no software Microsoft Exce ${ }^{\circledR}$ 2007, e os resultados foram apresentados como frequência (porcentagem) ou média \pm desvio padrão. As taxas de complicações, recorrência e cura foram calculadas.

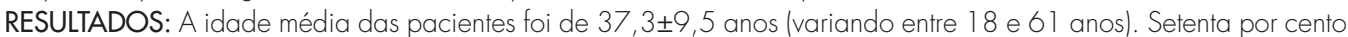
$(n=85)$ delas eram multíparas. A queixa mais frequente foi dor e $47,2 \%(n=60)$ das pacientes tinham antecedentes de tratamento médico e/ou cirúrgico por abcesso da glândula de Bartholin. A dimensão média dos cistos foi de 2,7士0,9 $\mathrm{cm}$. Foram verificados três $(2,4 \%)$ casos de hemorragia intraoperatória ligeira e $17(13,4 \%)$ recorrências durante um período médio de 14,6 meses (variando entre 1 e 56 meses): dez abscessos da glândula de Bartholin e sete cistos recorrentes, que precisavam de uma nova intervenção cirúrgica. A taxa de cura após um único tratamento à laser foi de $86,6 \%$. Dentre as cinco pacientes com doença recorrente que foram submetidas a um segundo procedimento com laser, a taxa de cura foi de 100\%. CONCLUSÕES: Na presente instituição, a vaporização laser com $\mathrm{CO}_{2}$ parece ser uma opção terapêutica segura e eficaz no tratamento dos cistos da glândula de Bartholin.

Correspondence

Ana Cristina Neves Figueiredo Rua do Viriato, $1069-089$ Lisbon, Portugal

Received $16 / 07 / 2012$

Accepted with modifications

$09 / 19 / 2012$
Study carried out at the Ginecology Service of Doutor Alfredo da Costa Maternity - Centro Hospitalar Lisboa Central - Lisbon, Portugal.

IIntern at Internato Médico de Ginecologia-Obstetrícia, Doutor Alfredo da Costa Maternity, Centro Hospitalar de Lisboa Central Lisbon, Portugal.

${ }^{2}$ Hospital Assistants of Ginecology and Obstetrics at Unidade de Patologia Cervico-Vulvo-Vaginal, Doutor Alfredo da Costa Maternity, Centro Hospitalar de Lisboa Central - Lisbon, Portugal.

${ }^{3}$ Chief of Ginecology and Obstetrics Service; Director of the Ginecology Service at Doutor Alfredo da Costa Maternity, Centro Hospitalar de Lisboa Central- Lisbon, Portugal.

Conflict of interest: none. 


\section{Introduction}

The obstruction of Bartholin's gland duct as a result of trauma (namely during a mediolateral episiotomy or a posterior colporrhaphy) or of infection leads to cystic enlargement of these glands because of the continued mucus secretion ${ }^{1,2}$. Bartholin's gland cysts are the most common cystic growths occurring in the vulva labia majora, affecting approximately $2 \%$ of women, mostly in reproductive years ${ }^{3}$. Although many patients are asymptomatic, Bartholin's gland cysts can be associated with significant discomfort and disruption of the sexual function and daily activities. Most common symptoms include pain, dyspareunia, fullness, and pressure or discomfort when sitting or walking ${ }^{1}$. Definite treatment is required not only to provide relief of symptoms but also to avoid the possibility of recurrent glandular abscesses ${ }^{4}$.

Although there are many treatment modalities available for this condition, the best approach is yet to be established ${ }^{5}$. Conventional treatments, like surgical excision and marsupialization, are still the most commonly used. Complete surgical excision, the first treatment described in 1942 by Catell ${ }^{1}$, requires general/regional anaesthesia and is associated with a complication rate of approximately $24 \% 3$. Its complications include: haemorrhage, infection of sutures, damage of surrounding structures, cosmetic disfigurement, dyspareunia, and disturbed lubrication of the vagina. Nevertheless, it remains the treatment of choice in two specific situations: recurrent cysts refractory to previous techniques and when there is a suspicion of adenocarcinoma of Bartholin's gland ${ }^{1,6}$. Marsupialization, first described in 1950 by Jacobson ${ }^{1}$, is a surgical alternative to the excision. It can be performed under local anaesthesia and has a lower risk of haemorrhage, scarring, postoperative pain and impaired sexual function, once it preserves the secretory function of Bartholin's glands for lubrication ${ }^{1,6}$. However, it has been associated with higher recurrence rates (from 2 to $25 \%)^{1}$.

In the past years, several authors have advocated the use of less-invasive but equally effective techniques for the treatment of this condition, like fistulization using Word catheter, alcohol sclerotherapy, or silver nitrate ablation ${ }^{5}$. Recently, outpatient carbon-dioxide $\left(\mathrm{CO}_{2}\right)$ laser vaporization of Bartholin's gland cysts has emerged as a safe and effective alternative, with several advantages over the conventional treatments. It has become the standard treatment approach of Bartholin's gland cysts in our institution since 2000 .

The aim of this retrospective study was to evaluate the effectiveness, recurrence rate, and complications of $\mathrm{CO}_{2}$ laser vaporization when treating Bartholin's gland cysts.
Methods

A retrospective study including 127 patients with symptomatic Bartholin's gland cysts submitted to $\mathrm{CO}_{2}$ laser vaporization at Maternidade Doutor Alfredo da Costa, Lisbon, Portugal, from January 2005 through June 2011. Patients with Bartholin's gland abscesses and those with neoplasia suspicion were excluded from the study. It was approved by the Ethics Committee of such Institution.

Clinical records of all patients were reviewed. Data concerning patient's history included: age, parity, contraceptive method, smoking habits, symptoms (pain, dyspareunia, and abnormal vaginal discharge), previous Bartholin's gland abscesses, and previous vulvar surgery. Preoperative assessment included gynecologic examination and vulvoscopy with assessment of location and size of the cyst.

All laser procedures were performed under local anaesthesia in an outpatient setting without the presence of a dedicated anaesthesiologist. We worked with a $50 \mathrm{~W} \mathrm{CO}_{2}$ Laser (Deka, Calenzano, Italy) with a power output of $25 \mathrm{~W}$ used in continuous mode, connected to a colposcope (Carl Zeiss, Oberkochen, Germany). The laser beam was guided by a manipulator and had a diameter that ranged from 0.5 to $1.0 \mathrm{~mm}$ and a power density from 600 to $1,200 \mathrm{~W} / \mathrm{cm}^{2}$. A $5 \mathrm{~mL}$ solution composed of $1 \%$ lidocaine without epinephrine was administered through multiple injections in the skin overlying the cyst. After managing the local anaesthesia, a $1.5 \mathrm{~cm}$ longitudinal incision with the laser beam near the place where the cyst wall was closer to the vulvar epithelium was performed. Afterwards, the cyst content was evacuated and a laser vaporization of the cyst capsule was carried out, with a depth of destruction from 2 to $3 \mathrm{~mm}$. Intraoperative and postoperative complications were recorded.

All patients received a seven-day course of Cefradine (1 g tid) postoperatively. Patients were advised to rest during the following week and instructed to return to the unit in case of significant pain or bleeding.

Follow-up visits were scheduled at two and six months after surgery and annually thereafter, where each one included a gynecologic and vulvoscopic examination with assessment of patients' symptoms or complaints (pain, dyspareunia and local paresthesia). Recurrence was defined as the occurrence of a gland cyst or abscess during the follow-up period, requiring new treatment.

Data were stored and analyzed in Microsoft Excel $^{\circledR} 2007$ software. A descriptive statistical analysis was performed and its results were expressed as frequency (percentage) or mean \pm standard deviation (SD). Complication, recurrence, and cure rates were calculated. 
Results

During the study period, 127 patients were submitted to $\mathrm{CO}_{2}$ laser vaporization of Bartholin's gland cysts at the mentioned unit.

Patients' characteristics are summarized in Table 1. The mean age was $37.3 \pm 9.5$ years (range from 18 to $61)$. Seventy percent $(n=85)$ of patients were multiparous, and hormonal contraception was recorded in 48 of them $(37.8 \%)$. About one quarter $(n=33$; $25.9 \%)$ of the patients referred smoking habits. Six percent $(n=8)$ of patients had previously undergone vulvar surgery: ipsilateral marsupialization in six cases, contralateral surgical excision in one, and laser vaporization of vulvar acuminate condiloma in one. Nearly half of the patients $(n=60 ; 47.2 \%)$ had a history of Bartholin's gland abscesses; of these, $38.3 \%$ $(\mathrm{n}=23)$ received medical treatment with antibiotics only and $61.7 \%(\mathrm{n}=37)$ had medical and surgical treatments (simple drainage in 31 cases, marsupialization in five, and partial surgical excision in one). Fifty-nine percent $(n=75)$ of patients referred only vulvar discomfort at the time of the procedure. Pain was the second most common symptom (29/31), followed by dyspareunia (9/31).

The mean cyst size was $2.7 \pm 0.9 \mathrm{~cm}$ (range from 1.5 to $5.0 \mathrm{~cm}$ ). The cysts were right-sided in $59(46.5 \%)$ cases and left-sided in $68(53.5 \%)$ ones.

All procedures were performed in an outpatient setting and all patients were discharged home after the treatment. The complication rate observed was 3.19\%. There were three $(2.4 \%)$ cases of minor intraoperative bleeding, easily controlled by haemostatic sutures, and one $(0.79 \%)$ case of postoperative hematoma, which was drained two days after surgery. No surgical site infections were recorded.

Concerning follow-up data, all patients attended the two-month follow-up examination. The mean duration of the follow-up was $29 \pm 21$ months (range from 2 to 83 months), as seen in Table 2.

At the first follow-up visit almost all patients $(n=115$; $90.6 \%)$ were symptom free. Six $(4.7 \%)$ participants referred pain and two $(1.6 \%)$ of them complained of dyspareunia. Healing was complete with two months in $94.5 \%(120 / 127)$ of patients and after three months in the remaining ones.

Overall, during the follow-up period, there were 17 $(13.4 \%)$ ipsilateral recurrences requiring retreatment. The mean latency before recurrence was 14.6 months (range from 1 to 56 months). There were ten ipsilateral Bartholin's gland abscesses that required medical and/or surgical treatments and seven recurrent symptomatic
Table 1. Baseline characteristics of the patients submitted to $\mathrm{CO}_{2}$ laser vaporization of Bartholin gland cysts $(\mathrm{n}=127)$

\begin{tabular}{lcc}
\hline Characteristics & $\mathrm{n}$ & $\%$ \\
\hline Age (years) & $37.3 \pm 9.5$ & \\
$\quad$ Mean \pm SD & $18-61$ & \\
$\quad$ Range & & \\
Parify & 42 & 33.1 \\
$\quad$ Nulliparous & 85 & 66.9 \\
$\quad$ Multiparous & & \\
Contraceptive method & 25 & 19.7 \\
$\quad$ None & 48 & 37.8 \\
$\quad$ Hormonal & 43 & 33.9 \\
$\quad$ Non-hormonal & 33 & 25.9 \\
Smoking habits & 8 & 6.3 \\
Previous vulvar surgery & 60 & 47.2 \\
Previous gland abscess & & \\
\hline
\end{tabular}

SD: standard deviation.

Table 2. Follow-up data of patients submitted to $\mathrm{CO}_{2}$ laser vaporization of Bartholin gland cysts

\begin{tabular}{lrrrr}
\hline \multirow{2}{*}{ Follow-up time } & \multicolumn{2}{c}{ Number of patients followed } & \multicolumn{2}{c}{ Number of recurrences } \\
\cline { 2 - 5 } & \multicolumn{1}{c}{$\mathrm{n}$} & $\%$ & $\mathrm{n}$ & $\%$ \\
\hline$<6$ months & 18 & 14.2 & 7 & 5.4 \\
6-12 months & 9 & 7.1 & 3 & 2.4 \\
12-24 months & 33 & 26 & 2 & 1.6 \\
24-48 months & 40 & 31.5 & 3 & 2.4 \\
$>48$ months & 27 & 21.2 & 2 & 1.6 \\
Total & 127 & 100 & 17 & 13.4 \\
\hline
\end{tabular}

cysts. Of these patients, five were submitted to a second outpatient laser vaporization procedure at our institution, with successful results in all cases. Two patients went under surgery again in other hospitals: one had a surgical excision and the other one a marsupialization. Both became asymptomatic after these procedures.

The cure rate after a single laser treatment was $86.6 \%(110 / 127)$. Among the five patients with recurrent disease, who had a second laser procedure, the cure rate was $100 \%(5 / 5)$.

\section{Discussion}

Bartholin's gland cysts account for $2 \%$ of all gynecologic visits per year ${ }^{1}$. Despite being a common condition, controversy remains on which therapeutic modality should be considered the golden-standard of treatment. Conventional techniques, like excision or marsupialization, have a low recurrence rate but usually require general anaesthesia and are associated with haemorrhage, infection, delayed scarring, and dyspareunia. Other less invasive and cost-effective alternatives have been developed. 
Some authors advocate the use of the Word catheter, which is a safe and effective method (with recurrence rates of only $3 \%$ ), but that requires patients to return at least twice for completing the treatment ${ }^{3,4}$. Other main disadvantages of this approach are that the catheter may be irritating and often dislodges or falls out before the tract is epithelialized.

Another approach is the cyst capsule destruction with silver nitrate or alcohol. Both are fast outpatient procedures performed under local anaesthesia, but with common adverse effects. Silver nitrate ablation is frequently associated with chemical vulvar burning and labial edema. Alcohol sclerotherapy can lead to transient hyperemia, hematoma, tissue necrosis, and scarring ${ }^{1,5}$. A prospective randomized study published in $2009^{6}$ aimed at comparing the efficacy of marsupialization and silver nitrate in the treatment of 212 patients with symptomatic Bartholin's gland cysts. The authors concluded that both treatment modalities seem to be equally effective, with similar recurrence rates, although silver nitrate favours complete healing with less scar formation $(\mathrm{p}=0.007)$.

Recently, outpatient $\mathrm{CO}_{2}$ laser vaporization of Bartholin's gland cysts has emerged as a safe and effective alternative technique. It was first described by Davis ${ }^{7}$ in 1985 , who used laser to create a 1.5 $\mathrm{cm}$ neostoma that extended from the vulvar skin to the cystic cavity. Twelve (86\%) of the 14 treated patients required only one treatment (recurrence rate $-14.3 \%$ ). Most patients experienced minimal discomfort during and after the procedure, with no significant long-term morbidity. Other recent published studies corroborate the safety and efficacy of $\mathrm{CO}_{2}$ laser vaporization. In 2002, Penna et al. ${ }^{8}$ reported a case control retrospective cohort on 111 patients treated either by laser vaporization or laser excision. Both treatment modalities showed low recurrence $(1.8 \%)$ and complication (4.5\%) rates, although laser excision was associated with longer surgery time and higher patient discomfort. Panici et al. ${ }^{3}$ published a prospective observational study of a series of $19 \mathrm{pa}-$ tients submitted to a minimally invasive procedure, consisting of a single drainage with a $\mathrm{CO}_{2}$ laser used to create a new stoma on the original duct orifice. The procedure had a $10.5 \%$ of recurrence rate, with minimum intra and postoperative patient discomfort and high patient satisfaction. Similar results were observed by de Góis Speck et al. ${ }^{9}$, in 2007. Of the 22 patients submitted to laser vaporization, only two had relapses both solved using a second procedure. The average surgery time was short, without bleeding during the operation and complete epithelization was achieved within a maximum four-week span.

Fambrini et al. ${ }^{4}$ reported in 2008 the largest case series on laser vaporization of Bartholin's gland cysts. In this retrospective analysis of 200 patients, there were nine $(4.3 \%)$ cases of recurrent disease, with a minimal complication rate $(1.5 \%)$. The cure rate after a single laser treatment was $95.7 \%$ and repetition of the laser procedure was effective in all recurrent cases. A systematic review of literature published in $2009^{5}$ aimed at evaluating the recurrence, healing time, and complications of different treatments for Bartholin's gland cysts or abscesses. The authors concluded that all of the available treatments are associated with low recurrence rates (less than 20\%), rapid healing (in two weeks or less), and uncommon non-life threatening adverse events. Nevertheless, this review failed to identify the best treatment approach for this condition according to the current literature.

In the present study, we retrospectively analysed 127 cases of Bartholin's gland cyst managed by $\mathrm{CO}_{2}$ laser vaporization. All procedures were completed in an outpatient basis, with low intraoperative and postoperative complication rates. Follow-up data revealed a recurrence rate of $13.4 \%$ during an average time of $29 \pm 21$ months. The cure rate after a single laser treatment was of $86.6 \%$. Among the patients with recurrent disease that had a second laser procedure, cure rate was $100 \%$.

The higher recurrence rate observed in this study comparatively to other reports can be, in part, explained by the presence of unrecognized multiloculated cysts, one of the most common causes of relapsing disease because of the difficulty of achieving complete evacuation. On the other hand, it can also be attributed to the fact that the procedures were performed by different surgeons, and one must not forget the impact of the long learning curve on the follow-up data. Although laser $\mathrm{CO}_{2}$ is used in our institution since 1980, this type of surgical procedure started only in 2004, which can account for the higher recurrence rate observed.

This study has some limitations. To start, the retrospective nature of the study may lead to a lower accuracy of the data, although information has been collected by a single investigator. On the other hand, the different follow-up duration can have biased the recurrence rate seen. 


\section{References}

1. Marzano DA, Haefner HK. The Bartholin gland cyst: past, present, and future. J Low Genit Tract Dis. 2004;8(3):195-204.

2. Roch JA, Thompson JD. Te Linde's operative gynecology. 10th ed. Philadelphia: Lippincott Williams \& Wilkins; 2008.

3. Panici PB, Manci N, Bellati F, Di Donato V, Marchetti C, Calcagno $\mathrm{M}$, et al. $\mathrm{CO}_{2}$ Laser therapy of the Bartholin's gland cyst: surgical data and functional short and long-term results. J Minim Invasive Gynecol. 2007;14(3):348-51.

4. Fambrini M, Penna C, Pieralli A, Fallani MG, Andersson KL, Lozza $\mathrm{V}$, et al. Carbon-dioxide laser vaporization of the Bartholin gland cyst: a retrospective analysis on 200 cases. J Minim Invasive Gynecol. 2008;15(3):327-31.

5. Wechter ME, Wu JM, Marzano D, Haefner H. Management of Bartholin duct cysts and abscesses: a systematic review. Obstet Gynecol Surv. 2009;64(6):395-404.
6. Ozdegirmenci O, Kayikcioglu F, Haberal A. Prospective randomized study of marsupialization versus silver nitrate application in the management of bartholin gland cysts and abscesses. J Minim Invasive Gynecol. 2009; 16(2):149-52.

7. Davis GD. Management of Bartholin duct cysts with the carbon dioxide laser. Obstet Gynecol. 1985;65(2):279-80.

8. Penna C, Fambrini $M$, Fallani $M G$. $\mathrm{CO}_{2}$ laser treatment for Bartholin's gland cyst. Int J Gynaecol Obstet. 2002;76(1): 79-80.

9. de Góis Speck NM, Belfort PN, Mendes P, Kang HJ, Ribalta JC. Carbon Dioxide Laser Treatment of Bartholin's Gland Cyst. Clin Exp Obstet Gynecol. 2007;34(1):50-1. 